by Abdulkader M. Abed, Issa M. Makhlouf, Belal S. Amireh, and Basem Khalil

\title{
Upper Ordovician glacial deposits in southern Jordan
}

\begin{abstract}
Glaciofluvial deposits that crop out in southern Jordan are reported here for the first time and are separated from the marine Mudawwara Formation under the name Ammar Formation. They are of Late Ordovician (Ashgillian to early Llandoverian) age and form an inseparable part of the northern African-Arabian glacial event. Glacial evidence includes paleovalleys cut deep into the Mudawwara Formation, various types of faceted and striated exotic clasts, and possible reworked tillites and striated channel basement. The general direction of flow was to the north and northeast, which is consistent with the flow in the equivalent Sarah Formation to the south in Saudi Arabia.
\end{abstract}

\section{Introduction}

A Late Ordovician glacial event has received the attention of geologists since the early $1970 \mathrm{~s}$. Several papers have been published about the deposits, which are found irregularly throughout an area of about $6,000 \mathrm{~km}$ on the Gondwana continent. They extend from Sierra Leone in western Africa (Tucker and Reid, 1973) to the Hoggar Mountains in southern Algeria (Beuf and others, 1966; Biju-Duval, 1974) through southeastern Libya (Bellini and Massa, 1980), southern Egypt and the northeastern Sinai (Issawi and Jux, 1982), and into northwestern and central Arabia (McClure, 1978; Vaslet, 1990) (fig. 1). The aim of this paper is to document, for the first time, the Ordovician glacial deposits in southern Jordan.

\section{Geologic setting}

Southern Jordan is covered completely by Paleozoic sandstone formations. Toward the eastern, northeastern, and southeastern parts of this area, clastic strata are added gradually so that they make up nearly a complete section from Cambrian to Upper Silurian age where they pass into northwestern Saudi Arabia (fig. 2). On the contrary, strata are removed toward the north-northwestern part of the area until only Cambrian rocks are present at the eastern shore of the Dead Sea. Gvirtzman and Weissbrod (1984) proposed that a geanticline existed during the Paleozoic and had its crest to the north-northwest near Gaza, which would explain this phenomenon. Because of the location of the most complete section, the study area is located in the extreme south of Jordan (fig. 2). Unfortunately, most of Jordan was covered after the Paleozoic by carbonate, chert,

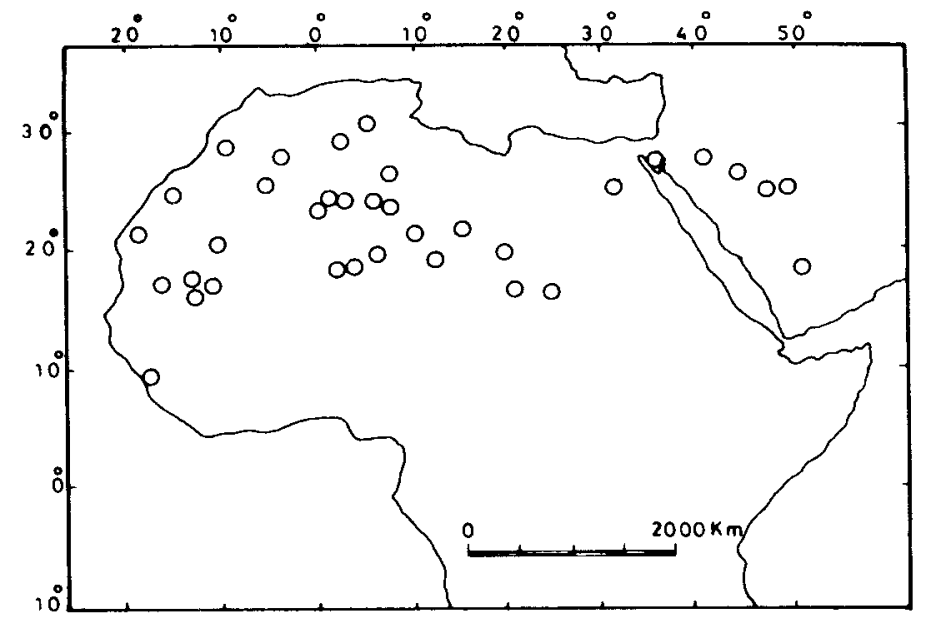

Figure 1. - Localities having proved glacial sediments of Late Ordovician age in Africa and Arabia (Tucker and Reid, 1973; Caputo and Crowell, 1985; Vaslet, 1990; this work).

and phosphorite deposits during the Late Cretaceous marine transgression, and this left only a small area for investigating the Late Ordovician glacial event.

\section{Preglacial rocks}

Several sandstone and shale formations are found below the evidence of the Late Ordovician glacial event. Following is a summary of these formations going from the older to the younger (Masri, 1988; Powell, 1989; Bender, 1974) (see fig. 3).

The first four formations belong to the Ram Group, which also crops out west of the study area. The Saleb Formation is a Lower to Middle(?) Cambrian, well-bedded, 30-80-m-thick arkosic sandstone that occupies depressions in the paleosurfaces of the Precambrian basement. This is overlain by the Umm Ishrin Formation of Late Cambrian to Early Ordovician(?) age. It is a brownish-colored, 230-250-m-thick fluvial quartzarenite containing many pebble horizons. The Disi Formation is Ordovician (Tremadocian to Arenigian) in age and is a white, friable, and pebbly quartzarenite that is $300-350 \mathrm{~m}$ thick. It is dominantly fluvial, but in its upper part, shale horizons containing Cruziana are present. The Umm Sahm Formation is Ordovician (Arenigian) in age. It makes up the uppermost part of the Ram Group and contains brownish, well-cemented sandstone and shale.

Overlying the Ram Group is the Khreim Group, which also is made up of four formations. The lower two formations preceded the glacial event. The Hiswah Formation dates from the Ordovician (Llanvirnian) and forms a distinct break in slope above the Ram Group. It is $70-80 \mathrm{~m}$ thick and consists of a lower graptolite-bearing 
mudstone member and an upper sandy member. The Dubaydib Formation is Ordovician (Llandeilian to Caradocian) in age and is about $160 \mathrm{~m}$ thick. This is a sandstone that is rich in Sabellarifex (Scolithos) at its bottom and top, and the middle part is a massive sandstone containing hummocky and trough crossbeds and channels. Above this formation is the Ordovician to Silurian Mudawwara Formation (Caradocian to late Llandoverian), within which glacial deposits are found. The lower member, the Tubeiliyat Member, is certainly older than the glacial deposits. but the Batra and Ratiya Members are younger. The Tubeiliyat Member is made up of sandstone up to $150 \mathrm{~m}$ in thickness. It consists of mesas and cuestas of alternating and laterally persistent sandstone and shale horizons (green) that show humnocky cross-stratification, ripple crosslamination, low-angle crossbedding, planar bedding, and ripple bedding (oscillation and ladder-back types). In addition. vertical burrows (Scolithos) are abundant. This member formed in a shallow-marine environment and is Caradocian to Ashgillian in age (Powell, 1989). The upper part of the Tubeiliyat Member is dominated by the greenish sandstone and shale, whereas the lower part is made of brownish sandstone.

\section{Glacial deposits}

Glacial deposits have not been recognized previously in Jordan and were mapped in part as Cretaceous sandstone (Bender, 1974). In the $1980 \mathrm{~s}$, these deposits were considered to be lateral facies changes within the Tubeiliyat Member of the Mudawwara Formation (Masri, 1988: Powell, 1989), which is equivalent to the Conularia sandstone unit (Bender, 1974) (fig. 3). J.H. Powell and B. Khalil (unpublished data) interpreted them as fluvial deposits and determined their stratigraphic position.

Detailed field investigations by the authors of this article revealed the completely different nature of the glacial deposits in comparison to the marine Mudawwara Formation. Subsequently, a new formation name, Ammar Formation, is proposed herein to include the glacial deposits (fig. 3). Renaming the Mudawwara Formation and its members will be proposed to the Geology Directorate in the Natural Resources Authority of Jordan.

\section{Ammar Formation}

Deposits of the glacial Ammar Formation are restricted to paleovalleys in a narrow belt that is about $4 \mathrm{~km}$ wide (northeast-southwest) and $70 \mathrm{~km}$ long (north-northwest-south-southeast) (figs. 2 and 4). The deposits extend from the Saudi Arabian border in the south around the Mudawwara police station (localities 1 and 2, fig. 4) until they disappear, along with the Paleozoic rocks, under the Upper Cretaceous sediments a little north of Jabal Ahmar (locality 8, fig. 4). The lower contact of the Ammar Formation is not seen in most of the outcrops because the bottoms of the deep cuts of the paleovalleys are in the subsurface. However, the glacial deposits in some other outcrops are found in shallower paleocuts (as much as $8 \mathrm{~m}$ ) in the topmost Tubeiliyat Member, which has a small erosional base (for example. Barga, locality 6. fig. 4; fig. 5a; and Wadi Arada east, locality 5, fig. 4). Here, the upper contact is always sharp and is marked by the deposition of the Batra Member. Three sections were measured and are described below (fig. 6).

\section{Hatiya section}

The Hatiya section is a 30 -m-thick succession of terrestrial glaciofluvial sediments measured in Wadi Al Hatiya (locality 7, fig. 4), $3 \mathrm{~km}$ northwest of Ammar and Umeir Hills. The lower boundary is an

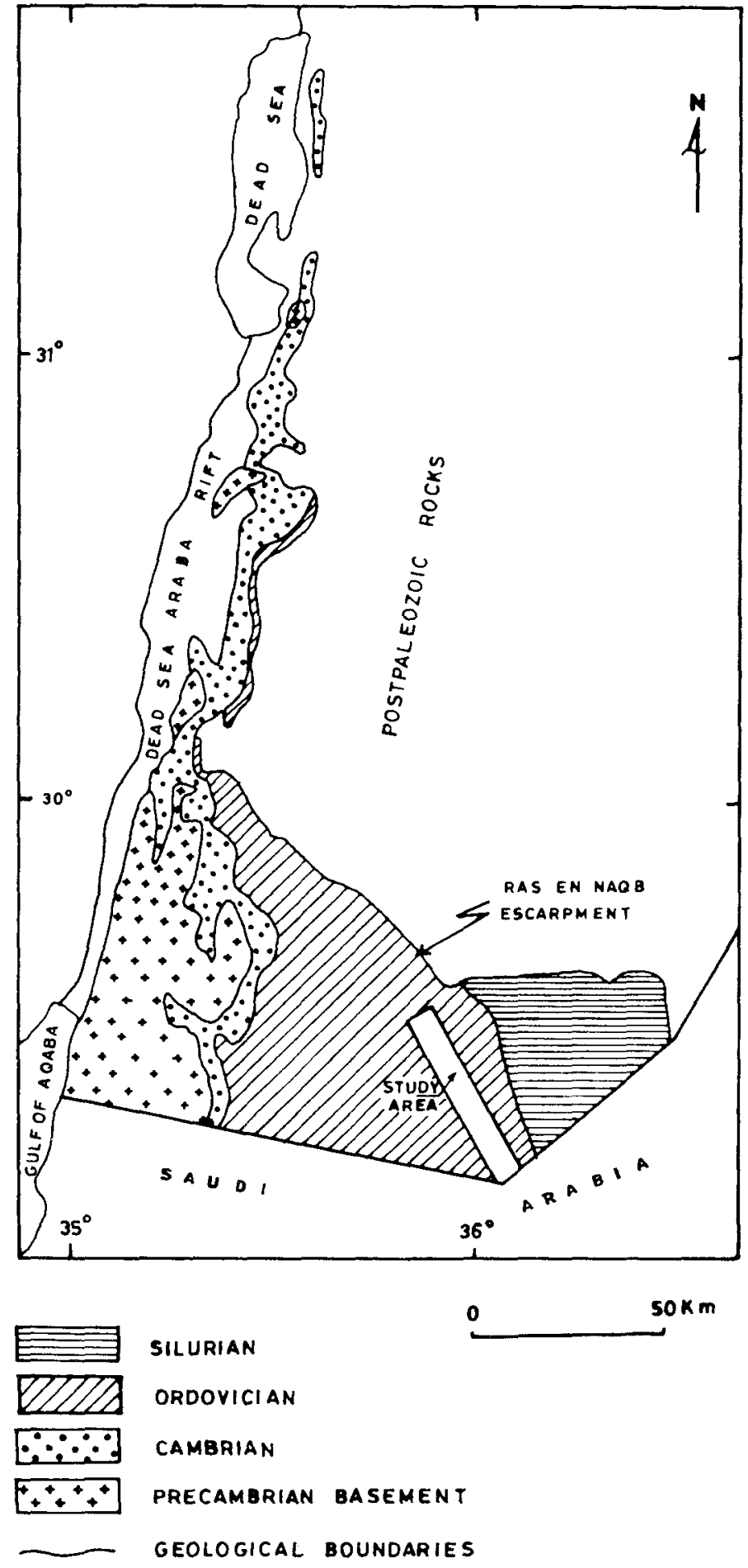

Figure 2.-Distribution of Paleozoic rocks in Jordan. Note the increase in strata toward the southeast and their disappearance to the north and northeast (modified from Bender, 1974). 


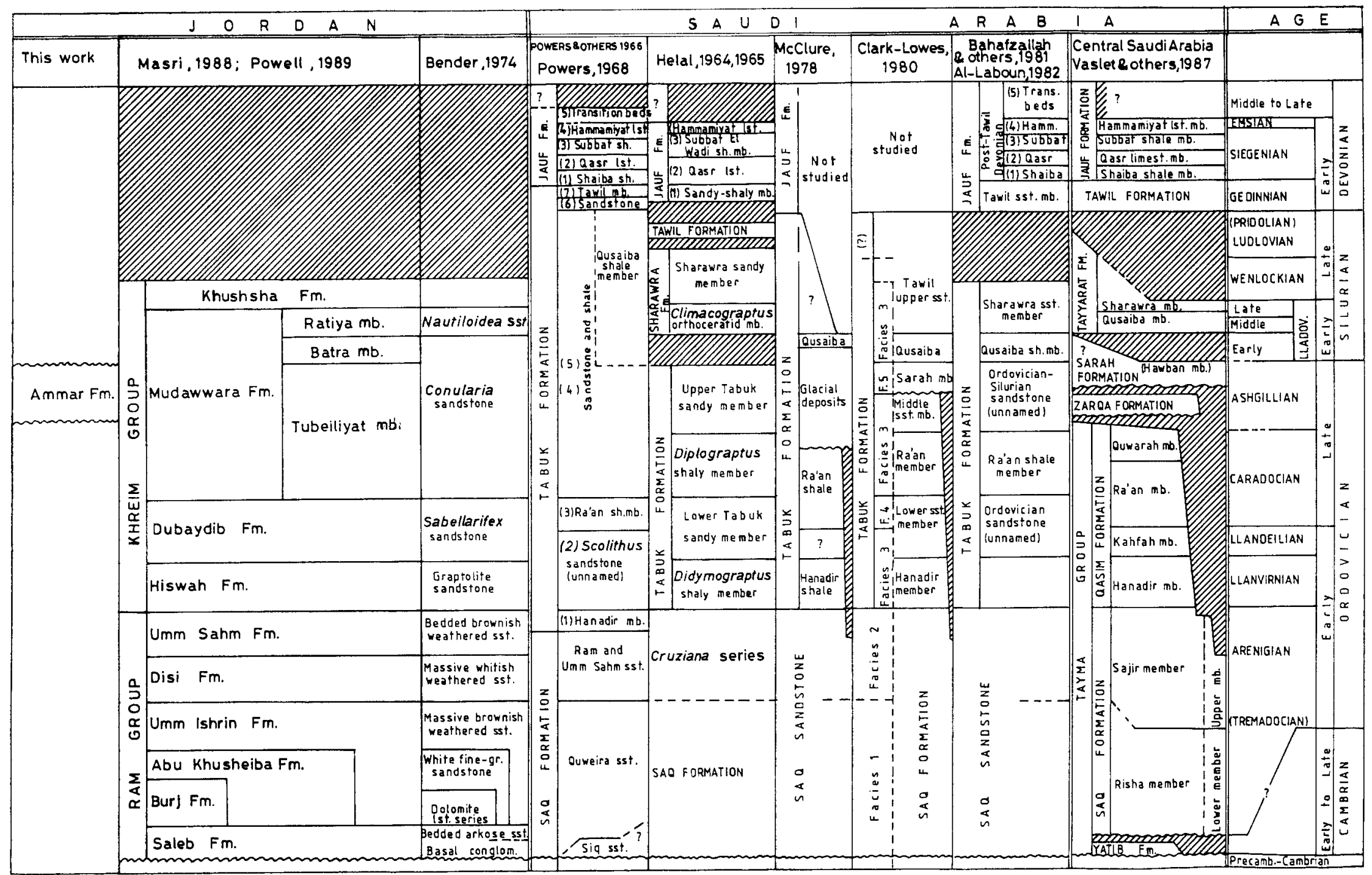

Figure 3. - Stratigraphic classification of Paleozoic rocks in Jordan and Saudi Arabia showing the position of the glacial Ammar Formation. Modified from sources shown and from Vaslet (1990). Abbreviations: conglom., conglomerate; f., facies; fm., formation; gr., grained; Hamm., Hammamiyat; lst., limest., limestone; Llandov., Llandoverian; mb., member; Precam., Precambrian; sh., shale; sst., sandstone; Trans., Transition. 


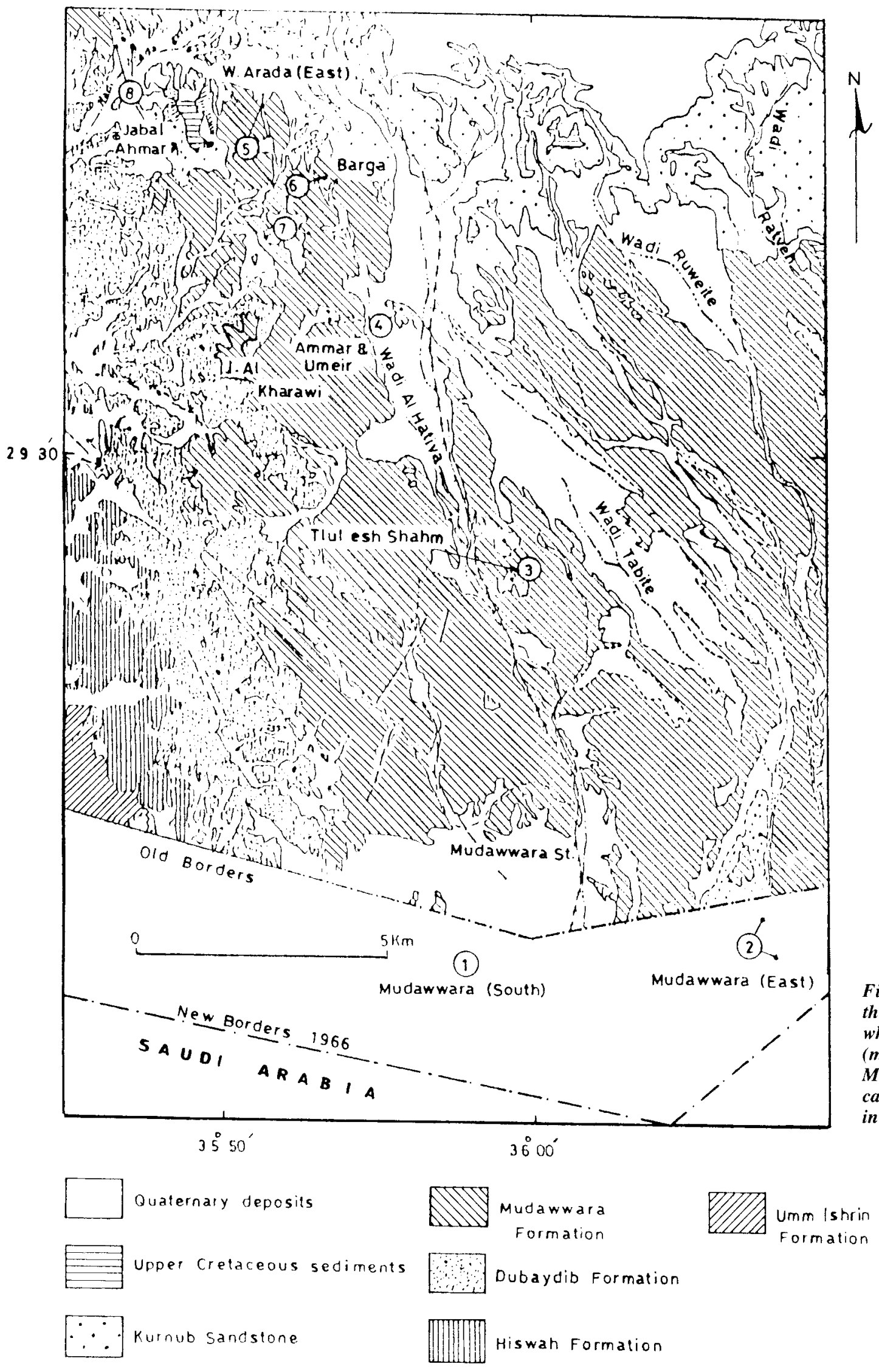

Figure 4.-Geological map of the area in southern Jordan where glacial sediments crop out (modified from Bender, 1974; Masri, 1988; Powell, 1989). Localities labeled $1-8$ are discussed in text. 
erosional unconformity cutting deep into the Tubeliyat Member. The succession can be divided into three distinct lithofacies (fig. 6).

Facies A is a channel-lag conglomerate that makes up the first 1 $\mathrm{m}$ of the succession above the erosional surface. It consists of exogenic components (rounded, striated, and faceted quartz pebbles and cobbles) and intraclasts of sandstones and siltstones. The morphology and surface textures of the pebbles are described below.

Facies B is green ball-and-pillow sandstone. It consists of green, silty sandstones exhibiting ball-and-pillow structures and exfoliation morphology. It attains a thickness of about $14 \mathrm{~m}$ here and is identical to that at Ammar and Umeir Hills (locality 4, fig. 4; fig. 6), but it is much thicker in the latter locality.

Facies B is enigmatic. It is similar in color and lithology to the green sandstone horizons of the underlying Tubeiliyat Member, but it has neither the vertical burrows present in the Tubeiliyat nor the Tubeiliyat's uniform bedding characteristics. It has various thicknesses depending on the depth of the paleocut in the green Tubeiliyat sediments, but it has no clear bedding surfaces and no microfossils, macrofossils, or trace fossils. It does not show any sedimentary structures that indicate a fluvial origin, nor does it have any evidence
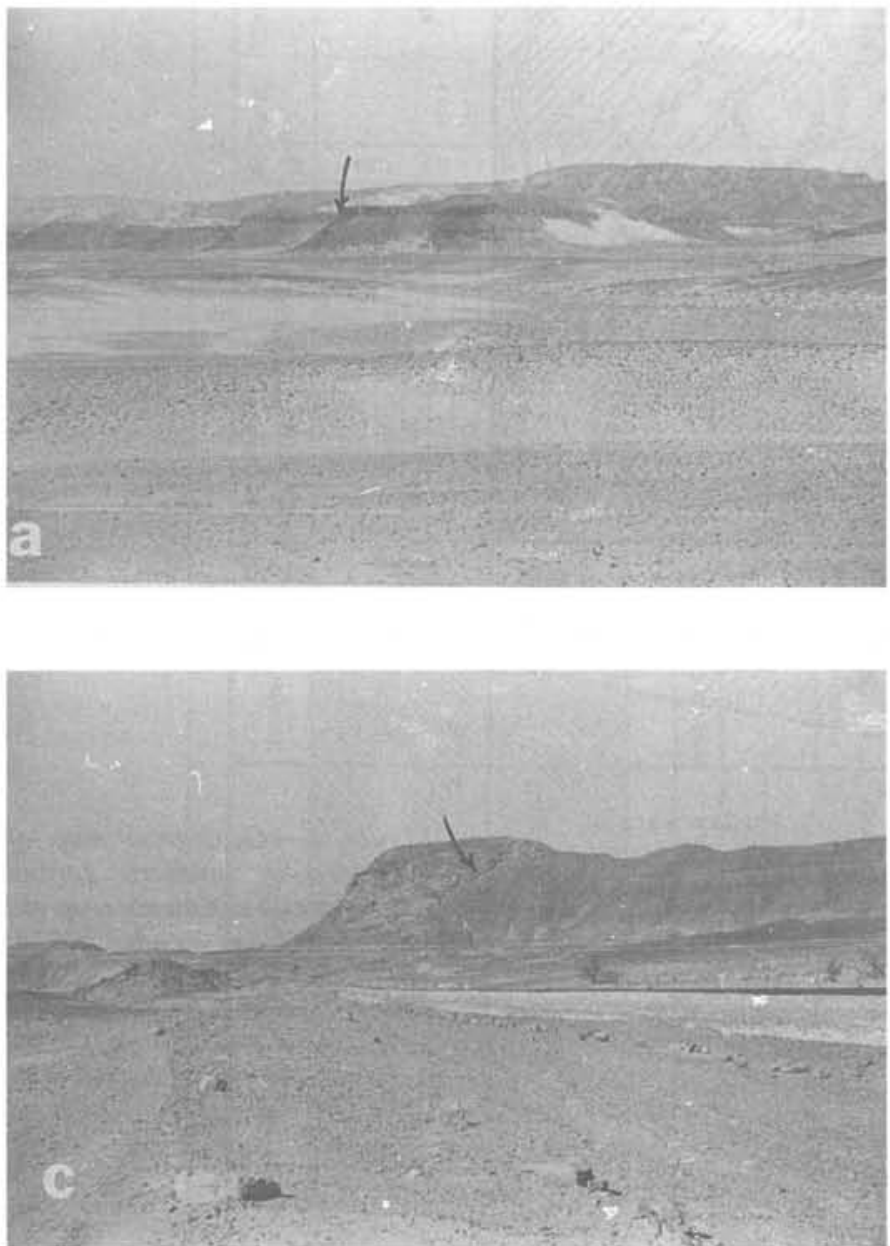

of a tillite. Most probably, it is a rock flour of the underlying, relatively soft, green sandstone of the Tubeiliyat, which was dumped quickly into the paleorelief. This is supported by both units' having almost identical clay minerals, light minerals, and heavy minerals (fig. 7, table 1).

Facies $\mathrm{C}$ is a rippled sandstone that is light brown, well sorted, and fine grained. Water-escape structures are common. The thickness is about $15 \mathrm{~m}$, and it is of terrestrial fluvial origin.

\section{Barga section}

To the north and northeast of the Hatiya section in the vicinity of Jabal Barga (locality 6, fig. 4; fig. 6), the glacial deposits are only 8 $\mathrm{m}$ thick in the topmost Tubeiliyat Member. Here, they consist of lithofacies that are similar to facies $\mathrm{A}$ and $\mathrm{C}$ of the Hatiya section. Beautifully striated and faceted clasts are abundant in the lower facies, and one small outcrop at the bottom of the channel exhibits a possible striated sandstone surface (fig. 5b). The upper facies is a trough-crossbedded sandstone that has its foreset azimuths uniformly directed toward the northeast $\left(60^{\circ}\right)$. This facies is overlain by the marine Batra Member.
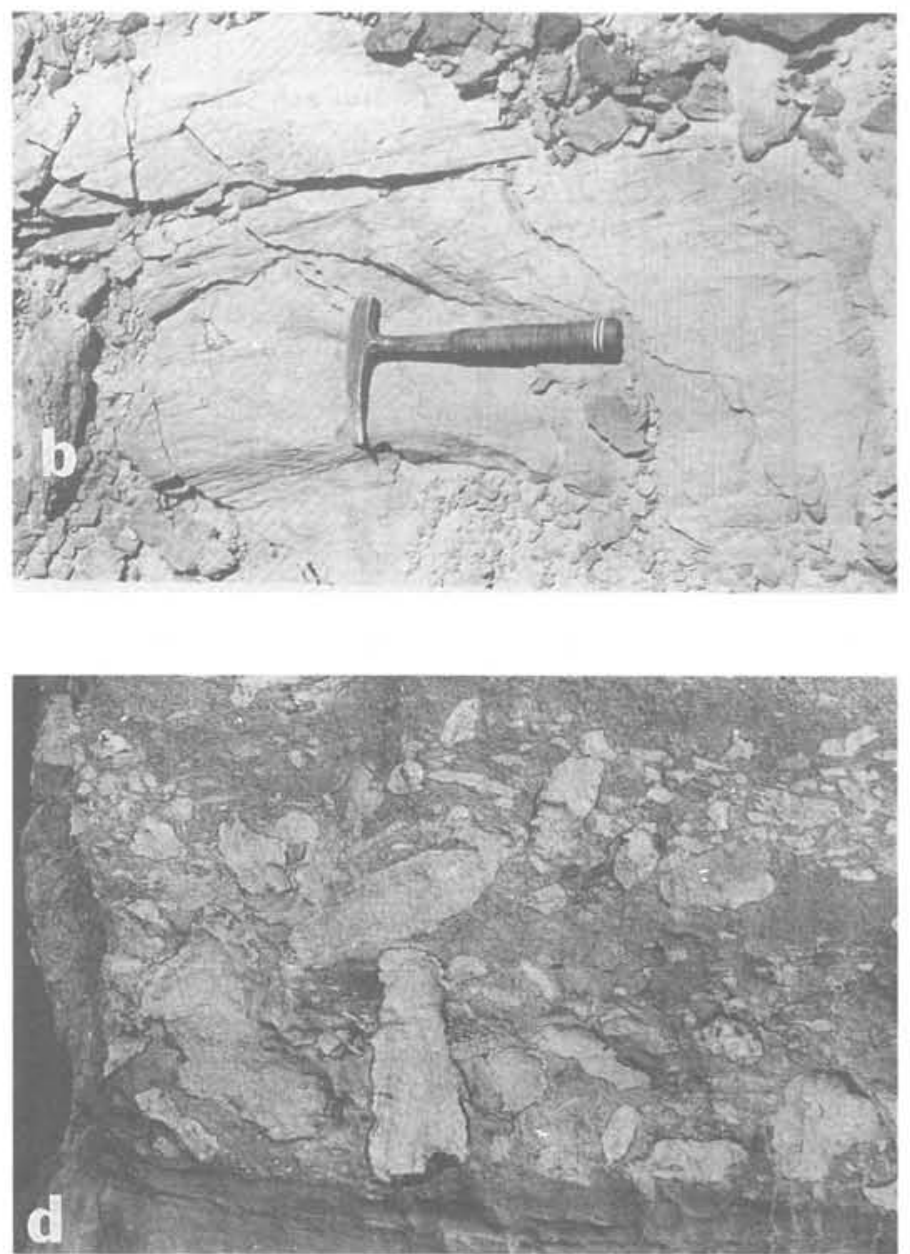

Figure 5.-Glacial features in Jordan. a, The 8-m-thick glacial Ammar Formation (at arrow) in Barga (locality 6, fig. 4). Note the underlying marine Tubeiliyat Member and the overlying marine Batra Member. b, Faint, possible striations at the bottom of a paleovalley in the Barga area. c, A paleovalley wall (arrow) serving as a contact between the Ammar Formation to the left and the marine Tubeiliyat Member to the right, $2 \mathrm{~km}$ northwest of Jabal Ahmar (locality 8, fig. 4). d, Lag conglomerate at the bottom of Jabal Ahmar. Clasts consist of greenish mudstone. Width of view is $175 \mathrm{~cm}$. 


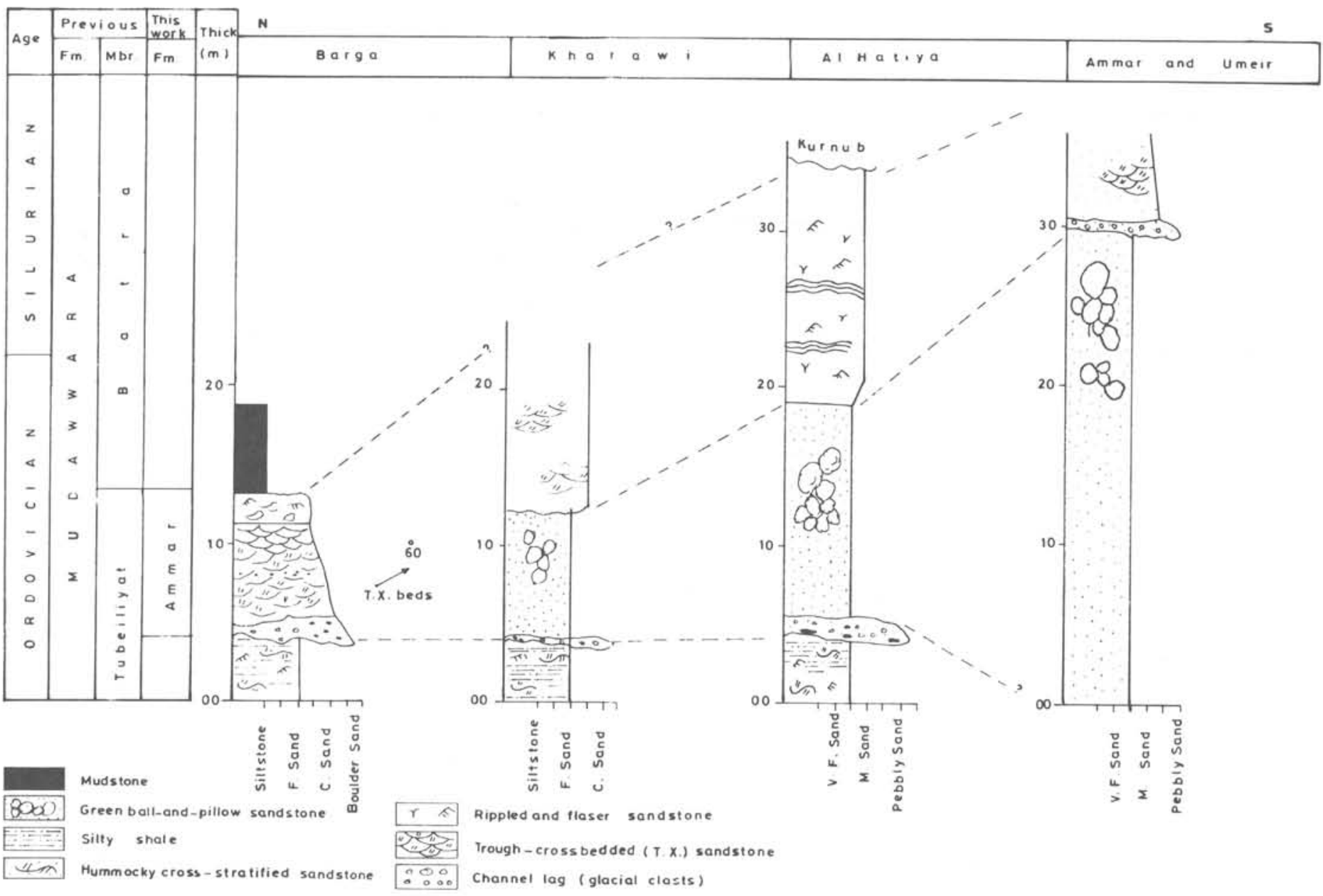

Figure 6. -Graphic logs of the Ammar facies in different localities of southern Jordan. Abbreviations: Fm., Formation; Mbr., Member; Thick, thickness; $N$, north; $S$, south; F., fine-grained; $C$., coarse-grained; v.f., very fine grained; M., medium-grained.

The green sandstone, facies B of the Hatiya section, is missing in this area, possibly as a result of the shallow cut of the paleovalleys.

The sandstone at these sections and at Ammar and Umeir Hills is arkosic to subarkosic (10-25 percent feldspar) and has a remarkable similarity among its light- and heavy-mineral suites (table 1) and its clay minerals. Accordingly, we can conclude that the sandstone fill of the paleovalleys certainly was derived locally (reworked or washed) from the underlying marine Tubeiliyat Member substrate. This mineralogical similarity agrees with the general observation that glacial deposits are derived from the local substrate or the immediately underlying rock unit (Spencer, 1975; Davis, 1983; Edwards, 1986).

Scanning electron microscopy (SEM) revealed no evidence in the sandstone for glaciation. This is because of the diagenetic syntaxial quartz overgrowth that probably canceled or masked any expected grain-surface textures of glacial origin (for example, concoidal fractures or crushing and abrasion features; Mahaney, 1990). However, such glacial features are well preserved in the enclosed pebbles and cobbles.

\section{Surface textures of pebbles and cobbles}

Faceting and striation of gravel-sized grains are among the strongest evidence for glacial action (Pettijohn, 1975; Davis, 1983; Edwards, 1986). Such features are displayed clearly in pebbles and cobbles of the Ammar Formation.

We observed clasts that have facets on one surface, on two opposite surfaces (tabulate), or on more than two surfaces. These facets can be smooth and have either faint striations or no visible striations (fig. 8a), or they can have well-defined striations (figs. $8 \mathrm{~b}$ and e). Many clasts have striations that show beyond a doubt the glacial origin of this feature (figs. $8 \mathrm{~b}-\mathrm{f}$ ). These striations commonly are oblique to the faceted surface. Sometimes two opposite facets are striated.

Many of the clasts have crushed margins, called by Wentworth (1936) "snub scars" (figs. 8c, d). In certain cases, not only the edge is snubbed, but the whole surface is broken (fig. 8e).

Flatiron-shaped clasts have roughly a triangular shape in a plane and a large faceted base that may or may not be striated. The margins are characterized by snub scars. In addition, we found a few wellpolished pebbles and cobbles. 
All of the described clasts are exotic quartz (probably vein quartz) and quartzite. However, we also found some faceted and striated granitic clasts (fig. $8 \mathrm{f}$ ) and a single faceted clast of microcline.

\section{Interpretation}

The sediments of the Ammar Formation in this area are confined to paleovalleys that were cut previously by the older action of glaciation. The facies distribution and thickness depend on the depth of the cut and on the composition of the reworked material (fig. 9). These sediments are dominantly of fluvial origin. The lag conglomerate (facies A), containing faceted and striated clasts, seems to be a reworked lodgment till, normally considered to form as a subglacial deposit (Drake, 1972; Boulton, 1978; Eyles and Miall, 1984). No typical tillite is encountered in the study area. This is as a result of later fluvial activities and the restrictions imposed by outcrops in the study area, which lacks the deep, pronounced topography described by Vaslet (1990) in northwestern and central Saudi Arabia.

\section{Jabal Ahmar section}

This section represents the northernmost outcrops of the glacial deposits (locality 8, fig. 4) and is some $70 \mathrm{~m}$ thick (fig. 10). The lower boundary is not exposed, and the upper boundary is eroded. The sediments are confined to a broad U-shaped valley (fig. $5 \mathrm{c}$ ) that is cut into deposits of the Tubeiliyat Member. The marine sediments of the Tubeiliyat are remarkably unsimilar to the exposed outcrops of this section.

The succession at Jabal Ahmar is made up of 11 well-defined sequences (cycles), each of which becomes finer grained going upward and ranges in thickness from $1.9 \mathrm{~m}$ to more than $18 \mathrm{~m}$ (figs. 10 and 11). Each cycle is made up of four distinct lithofacies that consist
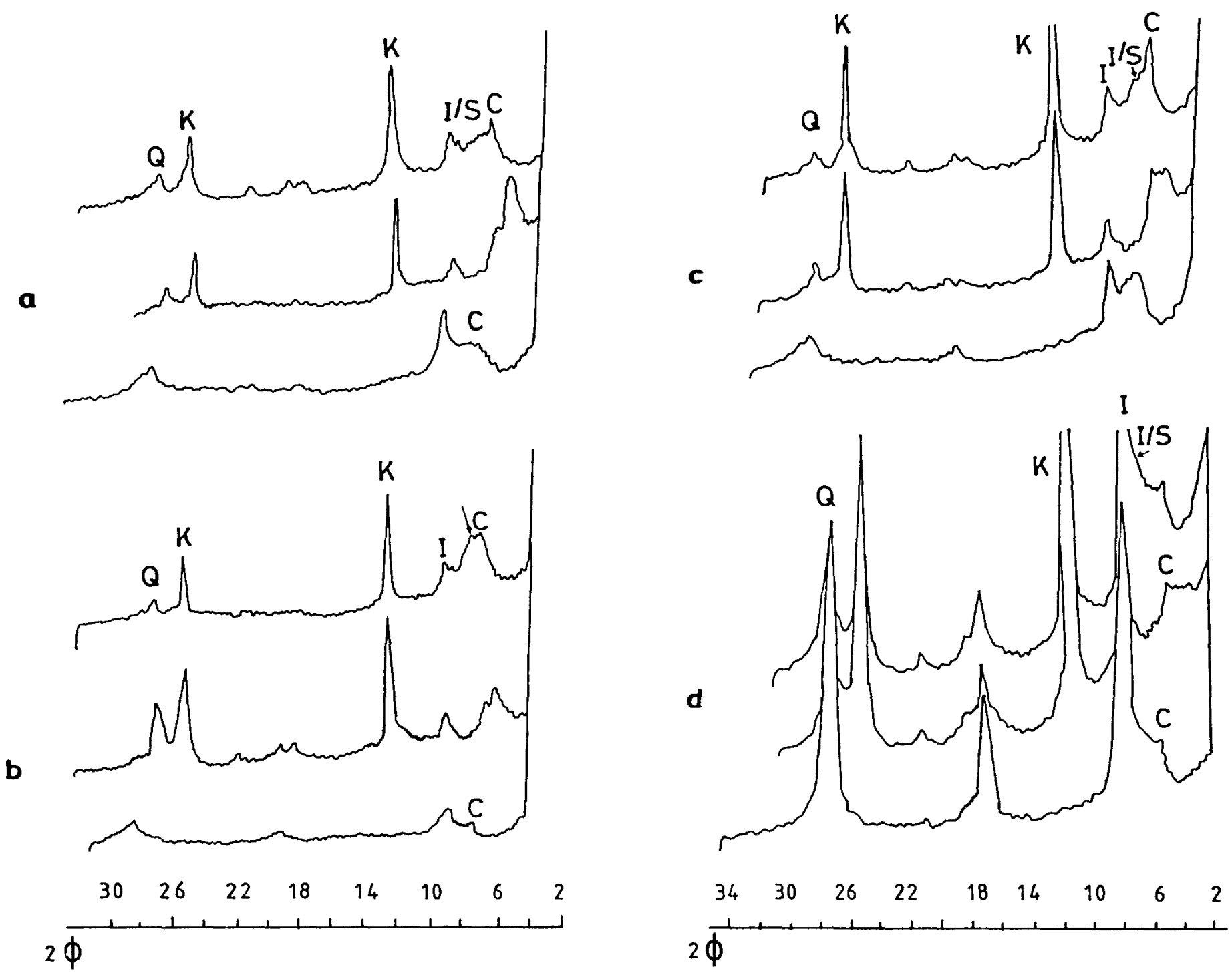

$2 \longdiv { \phi }$

Figure 7. - Clay minerals of the less than $2 \mu \mathrm{m}$ fraction of some selected samples of green sandstone and siltstone. a, Marine substrate of the Tubeiliyat Member. b, Ammar Hill. c, Hatiya. d, Mudstone clasts at the bottom of Jabal Ahmar. Diffractograms are normal (top), glycolated (middle), and heated to $550{ }^{\circ} \mathrm{C}$ (bottom). Abbreviations: $Q$, quartz; $K$, kaolinite; C, chlorite; $I$, illite; I/S, illite/smectite mixed layers. 
Table 1.-Modal analysis based on grain counts for samples from the Ammar Formation compared to a sample of the marine substrate

[Sample numbers: 1, marine substrate; 2-4, Jabal Ahmar; 5-9, Tlul esh-Shahm (locality 3, fig. 4); 10, 11, Jabal Arami; 12, Wadi Al Hatiya. t, trace; - , not detected]

\begin{tabular}{|c|c|c|c|c|c|c|c|c|c|c|c|c|}
\hline & 1 & 2 & 3 & 4 & 5 & 6 & 7 & 8 & 9 & 10 & 11 & 12 \\
\hline Particles & 71 & 68 & 69 & 76 & 70 & 69 & 73 & 74 & & & & 75 \\
\hline Quartz & 78 & 79 & 88 & 87 & 90 & 89 & 88 & 80 & & & & 75 \\
\hline Feldspars & 22 & 20 & 12 & 13 & 10 & 11 & 18 & 20 & & & & 25 \\
\hline Micas & $\mathrm{t}$ & 1 & - & - & - & - & - & - & & & & - \\
\hline Detrital matrix & - & 4 & 2 & - & 2 & 9 & 3.5 & 5 & & & & 2 \\
\hline Cements & 16 & 16 & 16 & 9 & 11 & 10 & 10.5 & 6 & & & & 10 \\
\hline Syntaxial quartz & 6 & 5 & 7 & 6 & 6 & 6 & 5 & 4 & & & & 3 \\
\hline Kaolinite & 2 & 6 & - & 1 & - & 1 & 2.5 & 2 & & & & 6 \\
\hline Iron oxides & 5 & 5 & 6 & 2 & - & 3 & - & - & & & & 1 \\
\hline Others & 3 & - & 3 & - & 5 & - & 3 & - & & & & - \\
\hline Pore spaces & 13 & 12 & 13 & 15 & 17 & 12 & 13 & 15 & & & & 13 \\
\hline \multicolumn{13}{|l|}{ Heavy minerals } \\
\hline Zircon & 49 & 30 & 72 & & 42 & & 60 & & 40 & 54 & 28 & \\
\hline Tourmaline & 24 & 22 & 15 & & 46 & & 33 & & 36 & 27 & 38 & \\
\hline Rutile & 10 & 9 & 5 & & 6 & & 7 & & 20 & 10 & 28 & \\
\hline Garnet & 17 & 31 & 7 & & 4 & & 2 & & 3 & 9 & 3 & \\
\hline Others & - & 8 & 1 & & 2 & & 1 & & 2 & - & 3 & \\
\hline
\end{tabular}

of, from the bottom to the top: lag conglomerate, trough-crossbedded sandstone, rippled and flaser sandstone, and silty claystone. Each individual cycle commences with an erosional base that has as much as $2 \mathrm{~m}$ of relief and contains abundant intraformational clasts and minor extraclasts.

Facies $\mathrm{A}$ is a lag conglomerate that has clasts made up dominantly of intraformational mudrocks and sandstones. These are soft, poorly sorted, highly irregular, very angular, and as much as $70 \mathrm{~cm}$ in length (fig. 5d). They must have been derived and deposited locally from a viscous flow. They are poorly imbricated, and the lowermost cycle shows a unidirectional orientation toward the northwest $\left(310^{\circ}\right.$ ) (fig. 10 ). Also, well-rounded quartz extraclasts up to 15 $\mathrm{cm}$ long are present. Most importantly, these extraclasts are not striated or faceted, in contrast to the quartz clasts in the outcrops to the southeast.

Facies B is a trough-crossbedded sandstone that consists of medium- to coarse-grained quartzitic sandstone and sparse granules. The trough crossbeds range from 1 to $8 \mathrm{~m}$ in width and from 0.2 to 1 $\mathrm{m}$ in thickness. They show a general tendency to decrease in thickness upward and to have a gradual decrease in grain size. A modal cycle direction toward the northwest was measured in the lower half of the succession, and a remarkable change toward the northeast was noted in the upper half (fig. 10).

Facies $C$ is made up of rippled and flaser sandstone that is composed of fine- to medium-grained sandstone having symmetric and asymmetric ripples, flaser bedding, cross-lamination, grooves, load casts, and water-escape structures. In the upper part of the succession, asymmetric ripples show a northeast paleocurrent direction, which is supported also by a northeast-southwest direction measured on the fluvial grooves.

Facies D consists of a silty claystone that represents the topmost facies in the fining-upward cycles. The upper surface normally is eroded (as much as $2 \mathrm{~m}$ of relief) and represents the base of channels that commonly are strewn with small, well-rounded clasts of quartz. and sandstone.

We are inclined to believe that the Jabal Ahmar glaciofluvial deposits belong to a relatively older glacial event. This is because the paleovalleys here are cut toward the bottom of the Tubeiliyat
Member (more than $100 \mathrm{~m}$ deep), rather than being a few tens of meters deep, as in the cases described above (fig. 9). Also, the lack of the green sandstone facies, which we found in the sections to the southeast, is taken here to mean that the Tubeiliyat's lower brown sandstones were cut through and reworked at an earlier time.

The paleocurrent direction in the lower part of the Jabal Ahmar section is to the northwest, whereas the upper part and other localities have a northeast direction. Is this an indicator of two glacial events, or is it a local trend? Once more, this is rather difficult to prove. Also, would the Jabal Ahmar section be equivalent to the Zarqa Formation in Saudi Arabia? We could not prove that because of the scarcity of outcrops in the small, isolated area in the extreme northnorthwest part of the study area (fig. 4) and because the present relief does not reveal the lower parts of the Jabal Ahmar section.

Interpretation. - Except for the clear, inclined boundaries of the paleovalley between the Jabal Ahmar sediments and the marine deposits of the Tubeiliyat Member and the possible reworked tillites (lag conglomerate, facies A), the confined deposits at the Jabel Ahmar section are typical of a braided fluvial regime (Allen, 1965; Miall, 1977). The general characteristics of the vertically stacked, fining-upward cycles on an eroded base are consistent with the scouring and filling of fluvial channels and the repeated erosion and deposition of these sediments. This may explain the lack of typical glacial deposits that are supposed to have been intermixed repeatedly in a fluvial regime.

\section{Age of glacial sediments}

Everywhere in the study area, the Ammar Formation cuts the upper part of the Tubeiliyat Member of the Mudawwara Formation and is overlain by the Batra Member of the same formation. Bender (1974) and Wolfart (1981) assigned a Caradocian to early Llandoverian age to these strata, which were called previously the Conularia sandstone unit (fig. 3). More recently, Powell (1989) identified the following graptolites from the Batra Member: Diplograptus modestus modestus and Glyptograptus ?tenuis, which indicate an early Llandoverian age, and Monograptus acinaces in the same member, which indicates a slightly higher zone in the lower Llandoverian deposits. The Ratiya 

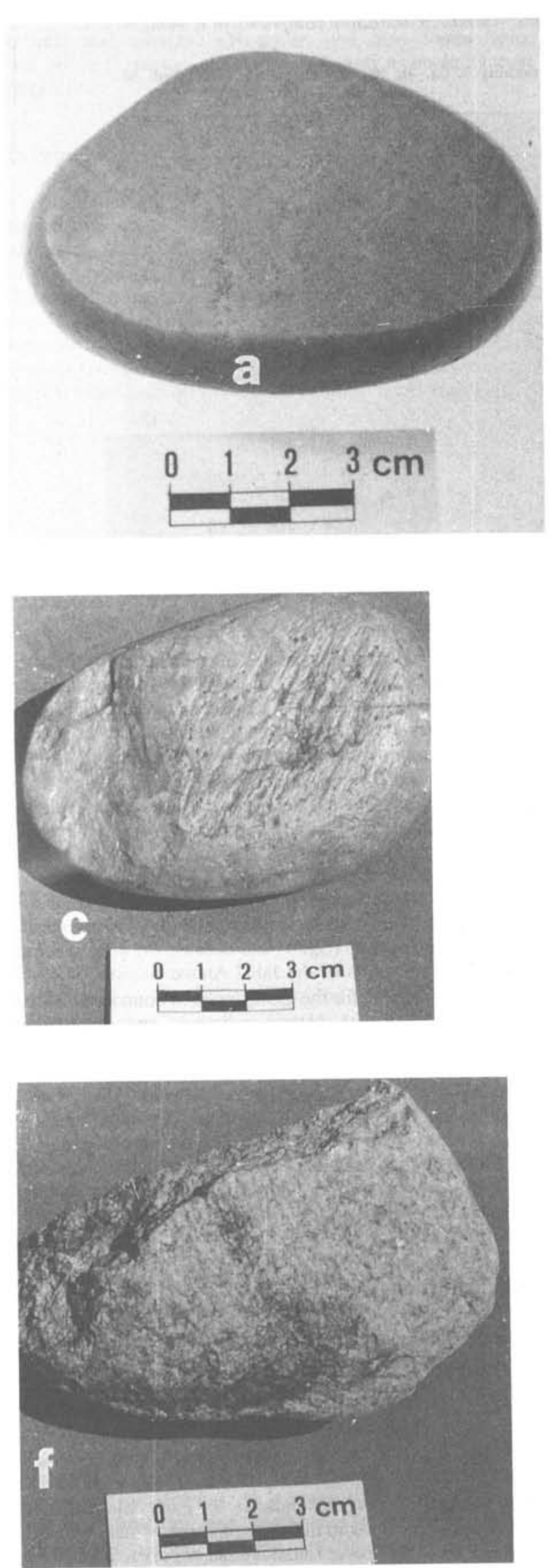
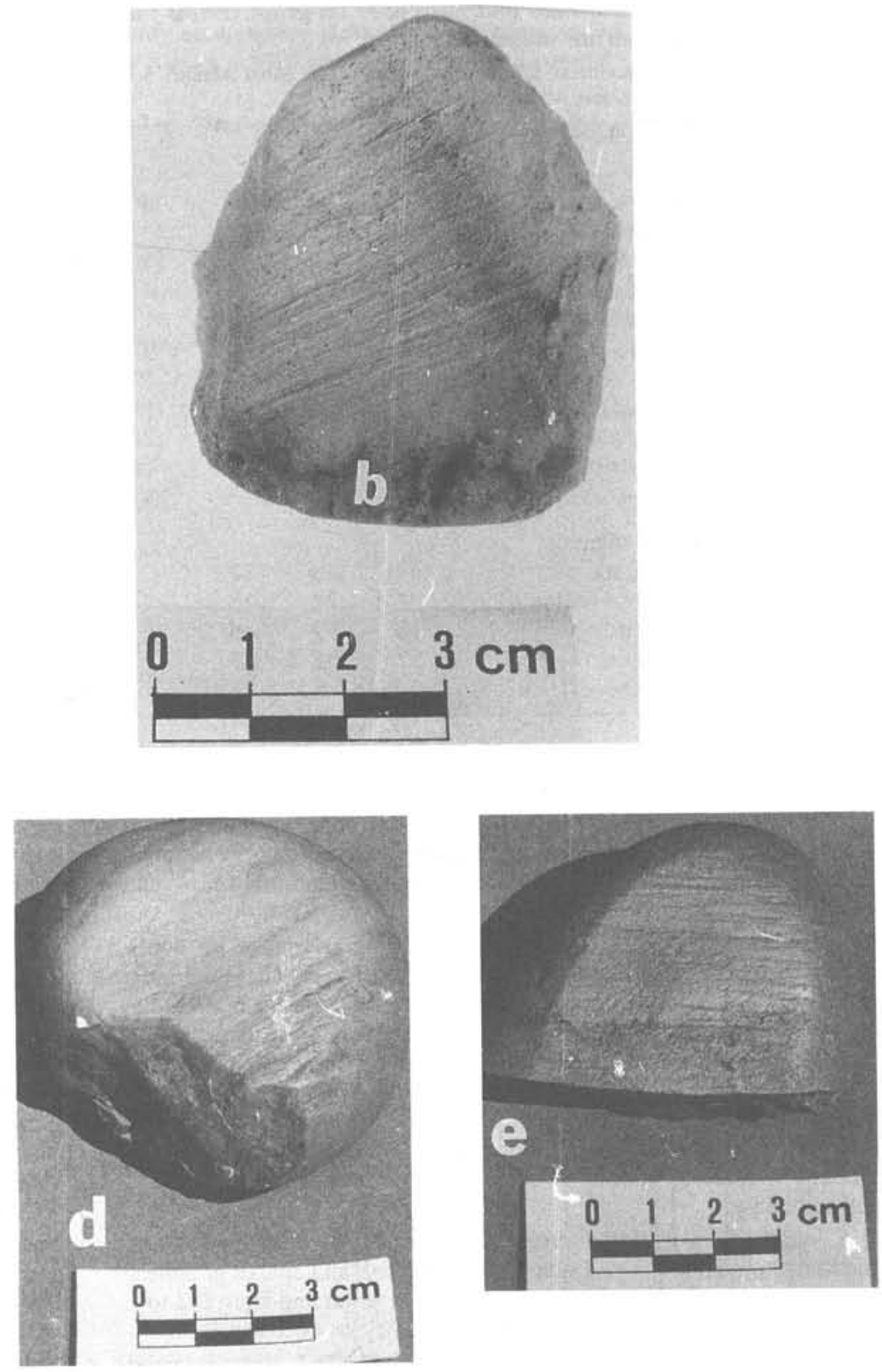

Figure 8.-Faceted and striated examples of pebbles and cobbles from the Ammar glacial sediments in southern Jordan. a, Faceted quartz cobble without any visible striations. b, Faceted and striated quartz pebble. $c$, Faceted, striated, and snubbed (on left) quartz pebble. d, Faceted, striated, and clearly snubbed quartz pebble. e, Faceted, striated, and broken quartz pebble. $f$, Faceted and striated granitic cobble. 


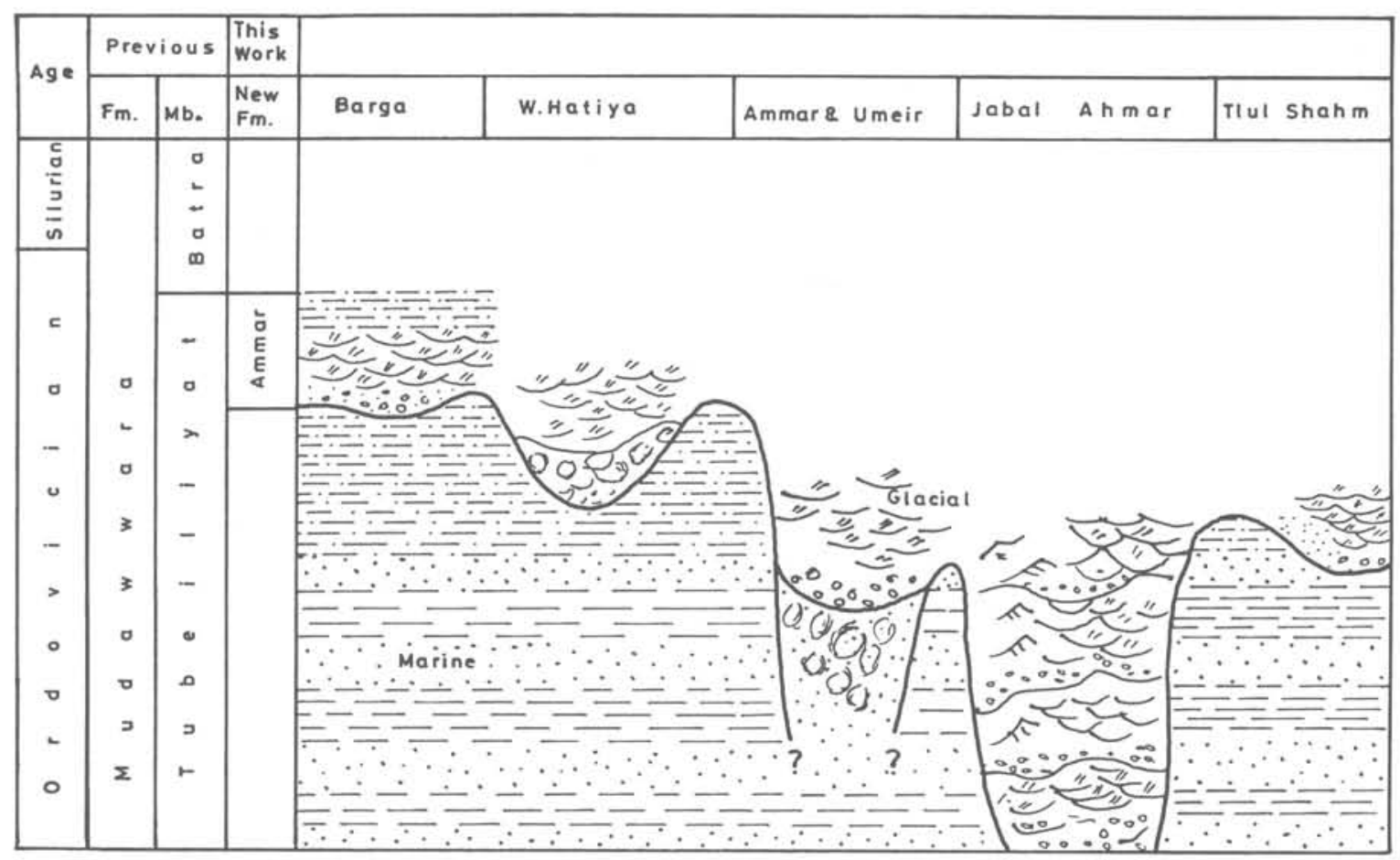

Figure 9. - Glacial paleovalley models and stratigraphic relationships in southern Jordan. Not to scale horizontally. See figure 6 for explanation of symbols. Abbreviations: Fm., formation; Mbr., Member; W., Wadi.

Member of the uppermost Mudawwara Formation was assigned an age of early late Llandoverian on the basis of Rastrites cf. perfectus Manek and Monograptus cf. sedgwickii (Powell, 1989). This member probably represents the time from late early Llandoverian to early late Llandoverian.

Thus, the age of the Mudawwara Formation is Caradocian to late Llandoverian, and the Ordovician-Silurian contact lies within this formation. Also, the glacial deposits (Ammar Formation) seem to have started sometime in the Ashgillian and continued into the early Llandoverian.

The age of the glacial Ammar Formation in Jordan fits well with the age of the glacial Sarah Formation in northwestern and central Saudi Arabia (Vaslet, 1990) (fig. 3). In addition, both of these glacial deposits are overlain by deposits (the Batra Member in Jordan and the Qusaiba Member in Saudi Arabia) that correlate nicely and indicate that a major marine transgression covered the terrestrial glacial deposits in the area.

\section{Discussion}

Evidence for Late Ordovician glaciation in southern Jordan includes (1) paleovalleys cut deep into the marine Mudawwara Formation, (2) ample and variable, faceted and striated exotic clasts, and (3) possible reworked tillites and striated channel basement. This evidence indicates that southern Jordan was subjected at that time, at least temporarily, to terrestrial ice action.

The lack of other glacial features like typical tillites and striated channel basement, such as have been reported in northwestern and central Saudi Arabia (Vaslet, 1990; McClure, 1978), probably is due to two factors. One factor may be the restriction caused by outcrops where the study area is of low relief and has no deep wadis. This area merges with the flat-lying southeastern desert where outcrops seldom are present. In addition, the study area is only about $75 \mathrm{~km}$ long, whereas the study area in Saudi Arabia was about 1,000 km long. Possibly the more important factor is that southern Jordan was situated a little off the terrestrial ice cap and, as a result, was not affected for a relatively long period by true glacial activities, as was the case for Saudi Arabia. Subsequently, previously deposited subglacial sediments and features were obliterated by outwash meltwater and water-laid sediment, which formed the fluvial sediments that now fill the paleovalleys. In fact, the reworking and eroding of continental tillites is a well-documented observation (Boulton, 1972; Pettijohn. 1975).

The glacial deposits in Saudi Arabia are essentially fluvial in nature (very much like those in Jordan) and have some tillites and striated channel basement in protected pockets. They also are the same age and have a similar paleocurrent direction that goes to the north and northeast. Thus, the two areas were part of the Late Ordovician glacial event.

Much has been written about the Late Ordovician glacial event in South America, northern Africa, and Arabia (for a review, see Caputo and Crowell, 1985, and Vaslet, 1990). We do not aim to review this subject but do indicate the following. Because the Late Ordovician glacial event in Arabia, Jordan, northern Africa, and eastern South America ended about early Llandoverian time, one can exclude the glacial sediments of southern Africa (Rust, 1981; Caputo and Crowell, 1985) from the above event, as they are Llandoverian in age and, therefore, are younger. This leads us to the observation that the sediments of the Late Ordovician event are stretched more in an east-west direction than in a north-south direction. Subsequently, the position of the glacial South Pole, the interpretation of which has been changing over the last 25 years, should be shifted more toward the east. An alternative to this is to reposition Gondwana in the Late Ordovician so that the Brazilian bulge would move more east- 


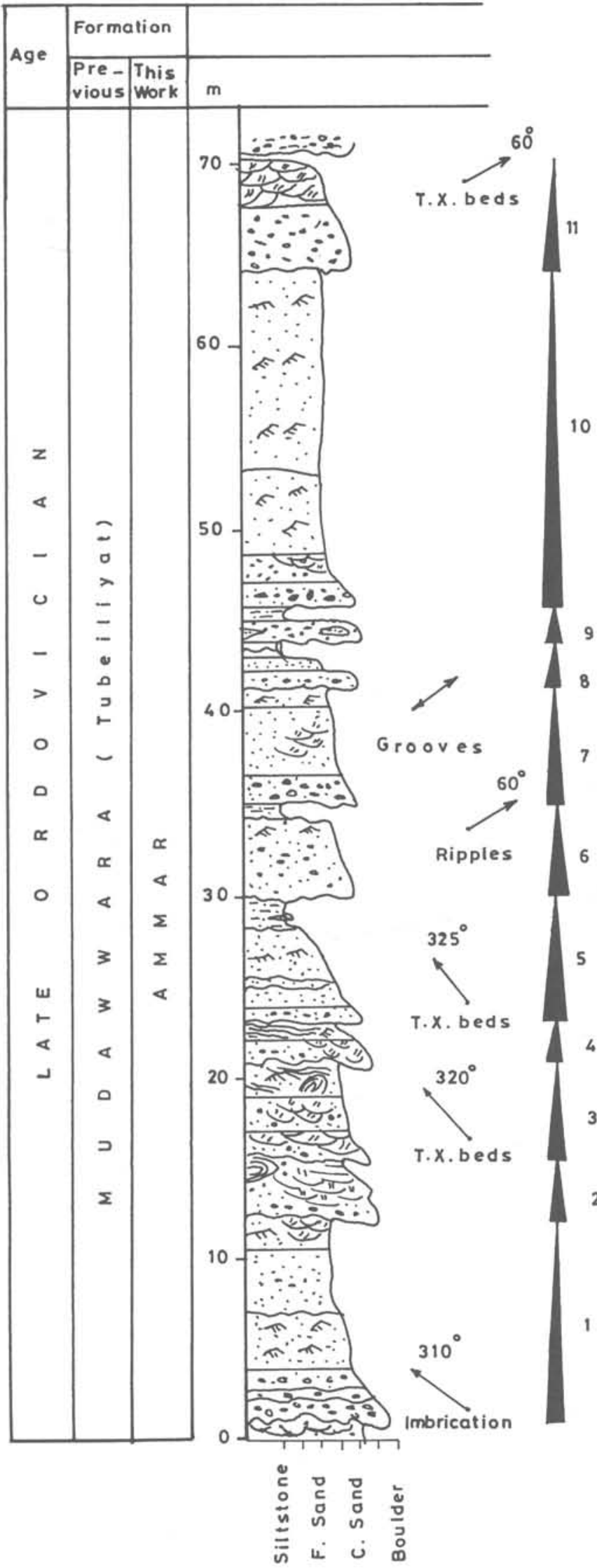

Silty claystone

s.r. Rippled and flaser sandstone

Trough - crossbedded (T.X.)

sandstone

$\therefore-10$ Channel lag

D) Deformed crossbedding

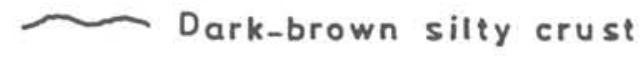

ح channeled base

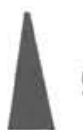

\section{Cycle}

Figure 10.-Columnar section of the Jabal Ahmar section in southern Jordan showing the cyclic pattern and trends of paleocurrents. See figure 6 for explanation of symbols. Abbreviations: F., fine-grained; $C$., coarse-grained.

southeast, and eastern northern Africa and Arabia would move more toward the northwest (fig. 12).

\section{Conclusions}

Late Ordovician glacial deposits in southern Jordan are restricted to a narrow belt that cuts the Late Ordovician marine Mudawwara Formation. The sediments are glaciofluvial and contain faceted and striated exotic pebbles and cobbles that are confined to paleovalleys of various depths and sizes. The name Ammar Formation is proposed herein to describe these deposits, which correlate nicely with the glacial Sarah Formation in Saudi Arabia. This glacial event ended in both countries sometime in the early Llandoverian. An older event, also Late Ordovician in age, is represented in Saudi Arabia by the Zarqa Formation and possibly may be equivalent to the Jabal Ahmar deposits in the extreme northwestern part of the study area. Arabia (including Jordan), northern Africa, and eastern Brazil appear to have been covered by an ice sheet that extended for several thousand kilometers during Late Ordovician time.

\section{References}

Al-Laboun, A.A., 1982. The subsurface stratigraphy of pre-Khuff formations in central and northwestern Arabia: Jiddah, King Abdulaziz University, $\mathrm{Ph} . \mathrm{D}$. thesis, $102 \mathrm{p}$.

Allen, J.R.L., 1965, A review of the origin and characteristics of Recent alluvial sediments: Sedimentology, v, 5, p. 89-191.

Bahafzallah A., Jux, U., and Omara, S, , 1981, Stratigraphy and facies of the Devonian Jauf Formation, Saudi Arabia: Neues Jahrbuch für Geologie und Paläontologie Monatshefte, v. 1, p. 1-18. 

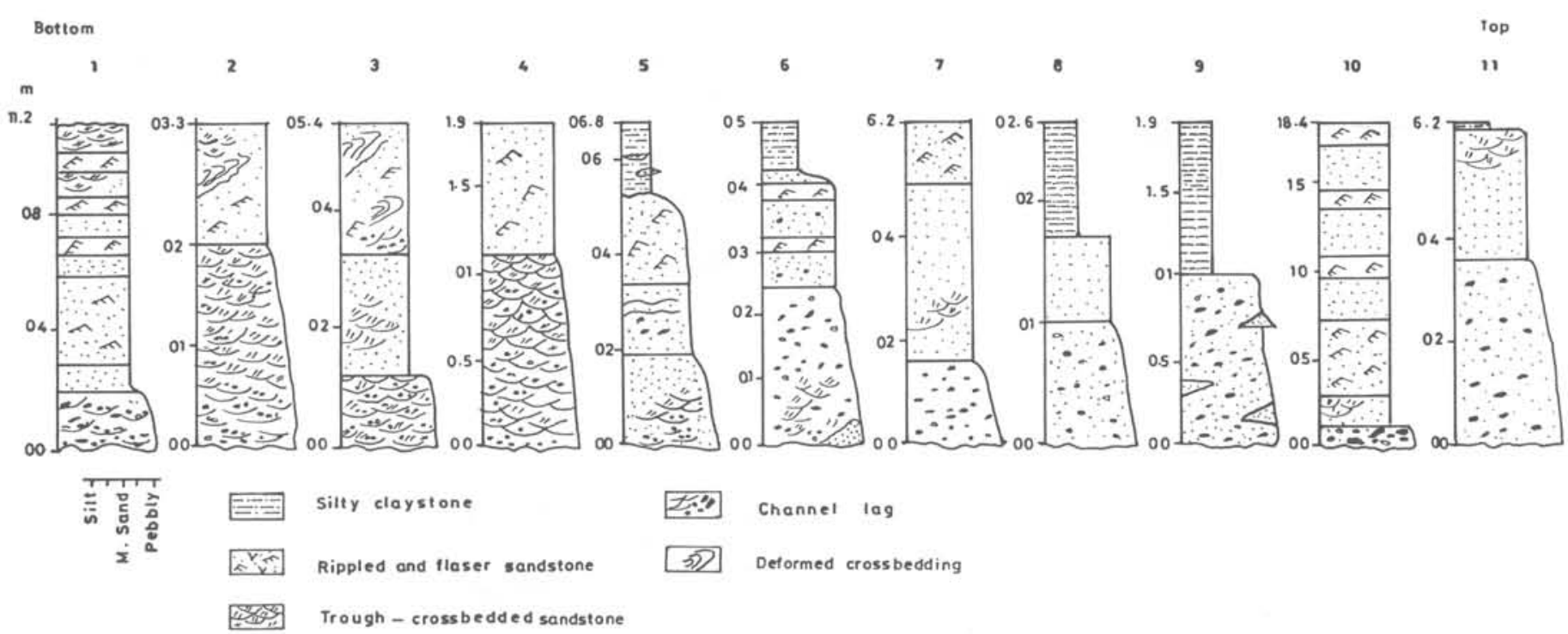

Figure 11.-Idealized fining-upward sequences found within the Jabal Ahmar terrestrial glaciofluvial deposits. Cycle numbers are keyed to figure 10. Abbreviation: M., medium-grained.

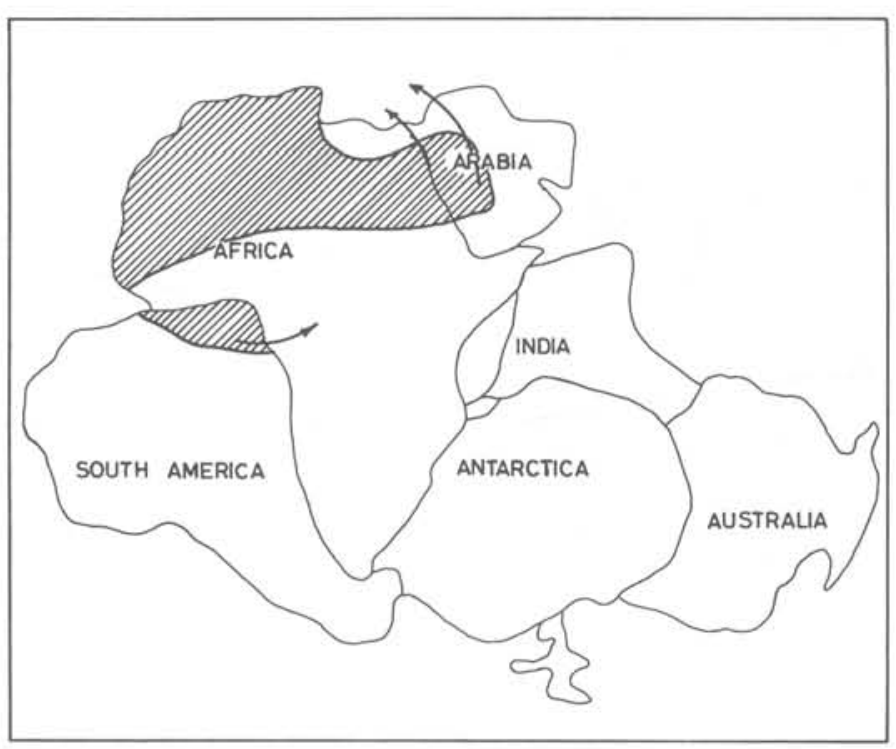

Figure 12.-Upper Ordovician sediments (patterned) in Gondwana. Arrows indicate suggested positions for these areas that would make the position of the glacial South Pole more symmetrical.

Bellini, E., and Massa, D., 1980, A stratigraphic contribution to the Paleozoic of the Southern Basins of Libya, in Salem, M.J., and Busrewil, M.T., eds., Geology of Libya: London, Academic Press, v. 1, p. 3-56.

Bender, F., 1974, Geology of Jordan: Berlin, Gebrueder Borntraeger, 196 p.

Beuf, S., Biju-Duval, B., Stevaux, J., and Kulbicki, G., 1966, Ampleur des glaciations "siluriennes" au Sahara, leurs influences et leurs consequences sur la sédimentation: Revue de l'Institut, Français du Pétrole, v. 21, p. 363-381.

Biju-Duval, B., 1974, Exemples de dépôts fluvio-glaciaires dans l'Ordovicien supérieur et le Précambrien supérieur du Sahara central: Bulletin du Centre de Recherches de Pau, v. 8. p. 209-226.
Boulton, G.S., 1972, Modern Arctic glaciers as depositional model for former ice sheets: Quarterly Journal of the Geological Society of London, v. 123 , p. $361-393$.

-1978 , Boulder shape and grain size distribution of debris as indicators of transport paths through a glacial and till genesis: Sedimentology, $v$. 25 , p. $773-779$.

Caputo, M.V., and Crowell, J.C., 1985, Migration of glacial centers across Gondwana during Paleozoic Era: Geological Society of America Bulletin, v. 96 , p. $1020-1036$.

Clark-Lowes, D.D., 1980, Sedimentology and mineralization potential of Saq and Tabuk formations: London, Imperial College of Science and Technology, Cover Rock Contract Open-File Report CRC/IC 7 and Saudi Arabian Directorate General of Mineral Resources Open-File Report DGMR-767, $88 \mathrm{p}$.

Davis, R.A., Jr., 1983, Depositional systems; a genetic approach to sedimentary geology: Englewood Cliffs, New Jersey, USA, Prentice-Hall, 669 p.

Drake, L.D., 1972, Mechanism of clast attrition of basal till: Geological Society of America Bulletin, v. 83, p. 2159-2166.

Edwards, M., 1986, Glacial environments, in Reading, H.C., ed., Sedimentary environments and facies: Oxford, Blackwell Scientific Publications, p. $445-470$.

Eyles, N., and Miall, A.D., 1984, Glacial facies, in Walker, R.G., ed., Facies models (2nd edition): Geological Association of Canada, Geoscience Canada Reprint Series 1, p. 15-38.

Gvirtzman, G., and Weissbrod, T., 1984, The Hercynian geanticline of Helez and the Late Palaeozoic history of the Levant, in Dixon, J.E., and Robertson, A.H., eds., The geological evolution of the eastern Mediterranean: Geological Society of London Special Publication 17, p. $177-187$.

Helal, A.H., 1964, On the occurrence of lower Paleozoic rocks in Tabuk area, Saudi Arabia: Neues Jahrbuch für Geologie und Paläontologie Monatshefte, v. 7, p. 391-415.

1965, Stratigraphy of outcropping Paleozoic rocks around the northern edge of the Arabian Shield (within Saudi Arabia): Zeitschrift der Deutschen Geologischen Gesellschaft, v. 117, p. 506-543.

Issawi, B., and Jux, U., 1982, Contributions to the stratigraphy of the Paleozoic rocks in Egypt: Geological Survey of Egypt Paper 64, 28 p.

Mahaney, W.C., 1990, Macrofabrics and quartz microstructures confirm glacial origin of Sunnybrook drift in the Lake Ontario basin: Geology, v. 18. p. $145-148$.

Masri, A., 1988, Halat Ammar and Al Mudawwara map sheet nos. 3248 III, 3248 IV: Jordan, Natural Resources Authority, Geology Division, Geological Bulletin 13, scale 1:50,000. 
McClure, H.A., 1978, Early Paleozoic glaciation in Arabia: Palaeogeography, Palaeoclimatology, Palaeoecology, v. 25, p. $315-326$.

Miall, A.D., 1977, A review of the braided river depositional environment: Earth-Science Reviews, v. 13, p. 1-62.

Pettijohn, F.J., 1975, Sedimentary rocks (3rd edition): New York, Harper \& Row, $628 \mathrm{p}$.

Powell, J., 1989, Stratigraphy and sedimentation of the Phanerozoic rocks in central and south Jordan, Part A: Ram and Khreim Groups: Jordan, Natural Resources Authority, Geology Division, Geological Bulletin 11, $72 \mathrm{p}$.

Powers, R.W., 1968, Lexique stratigraphique international, Asie, v. III, fascicule 10b1, Saudi Arabia: Paris, Centre National de la Recherche Scientifique, $177 \mathrm{p}$.

Powers, R.W., Ramirez, L.F., Redmond, C.D., and Elberg, E.L., Jr., 1966, Geology of the Arabian Peninsula: Sedimentary geology of Saudi Arabia: U.S. Geological Survey Professional Paper 560-D, $147 \mathrm{p}$.

Rust, I.C., 1981, Lower Palaeozoic rocks of southern Africa, in Holland, C.H., ed., Lower Palaeozoic rocks of the Middle East, eastern and southern Africa, and Antarctica, v. 3 of Lower Palaeozoic rocks of the world: Chichester, England, John Wiley, p. 165-187.

Spencer, A.M., 1975, Late Precambrian glaciation in the North Atlantic region, in Wright, A.E., and Moseley, F., eds., Ice ages: Ancient and modern: Liverpool, England, Seel House Press, p. 7-42.

Tucker, M.E., and Reid, P.C., 1973, The sedimentology and context of Late Ordovician glacial marine sediments from Sierra Leone, West Africa: Palaeogeography, Palaeoclimatology, Palaeoecology., v. 13, p. 289307.

Vaslet, D., 1990, Upper Ordovician glacial deposits in Saudi Arabia: Episodes, v. 13, p. 147-161.

Vaslet, D., Berthiaux, A., Le Strat, P., Kellogg, K.S., and Vincent, P.L., 1987, Geologic map of the Baq'a quadrangle, sheet $27 \mathrm{~F}$, Kingdom of Saudi Arabia: Saudi Arabian Deputy Ministry for Mineral Resources Geoscience Map GM-116 A, scale 1:250,000.

Wentworth, C.K., 1936, An analysis of the shape of glacial cobbles: Journal of Sedimentary Petrology, v. 6, p. 85-96.

Wolfart, R., 1981, Lower Palaeozoic rocks of the Middle East, in Holland, C.H., ed., Lower Palaeozoic of the Middle East, eastern and southern Africa, and Antarctica; v. 3 of Lower Palaeozoic rocks of the world: Chichester, England, John Wiley, p. 5-30. $\square$

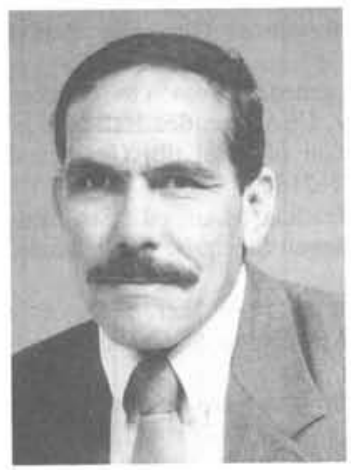

Abdulkader M. Abed is Professor of Geology, University of Jordan in Amman. He got his doctorate in sedimentary geochemistry in 1972 from Southampton University, England. His research is concentrated on Upper Cretaceous phosphorite, chert, and associated rocks. He is a member of the Mineralogical Society of Britain, the Society for Sedimentary Geology, and the International Association of Sedimentologists. He is also a member of the International Geological Correlation Programme's Scientific Committee in Paris (1990-1995).

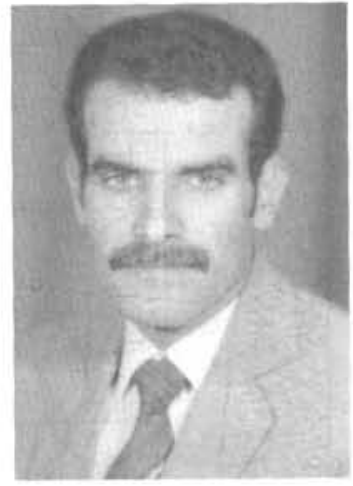

Dr. Issa M. Makhlouf is now an Assistant Professor of Geology, University of Sabha, Libya. Before that, he worked for the Natural Resources Authority in Jordan on sandstone sedimentology, his field of interest. He received his doctorate in 1987 from the University of Newcastle Upon Tyne, England.

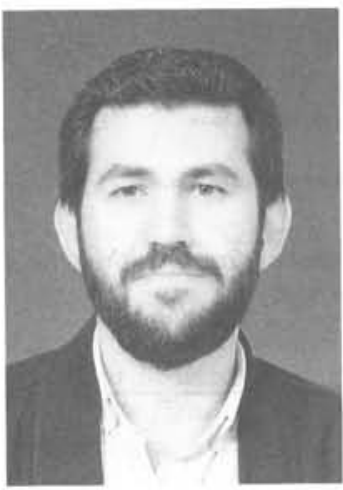

Dr. Belal S. Amireh is an Assistant Professor of Geology at the University of Jordan in Amman. He received his doctoral degree in sedimentology in 1987 from the Technical University of Braunschweig in Germany. Prior to joining the University of Jordan in 1991, he worked for 3 years as an Assistant Professor at Garyounis University, Libya. His main field of interest is sandstone petrography, particularly as related to heavy minerals and diagenesis.

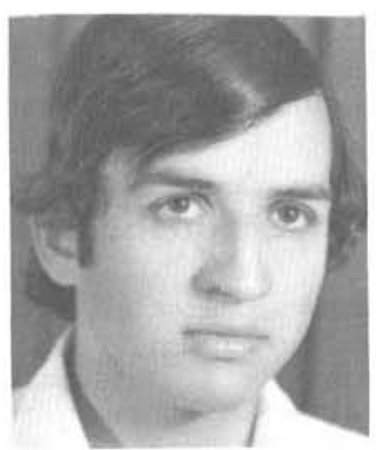

Basem Khalil received his master's degree in sedimentology in 1985 from the University of Jordan in Amman. He has had lengthy training in remote sensing in the UK and USA. Since 1984, he has worked as a field geologist in the National Mapping Project, Natural Resources Authority of Jordan, where he has concentrated on the Dead Sea transform and the eastern desert. His research interests include oil shale exploration and aggregate and building stones. 